\title{
Viability of Oomycete Propagules Following Ingestion and Excretion by Fungus Gnats, Shore Flies, and Snails
}

Naveen Hyder, Michael D. Coffey, and Michael E. Stanghellini, Department of Plant Pathology and Microbiology, University of California, Riverside 92521

\begin{abstract}
Hyder, N., Coffey, M. D., and Stanghellini, M. E. 2009. Viability of oomycete propagules following ingestion and excretion by fungus gnats, shore flies, and snails. Plant Dis. 93:720-726.

Sporangia of Phytophthora capsici and P. nicotianae, as well as hyphal swellings of Pythium splendens, $P$. sylvaticum, and $P$. ultimum, were ingested by adult shore flies but none were viable after passing through the digestive tract. Oospores of Pythium aphanidermatum retained their viability following ingestion by adult shore flies. Larval stages of fungus gnats and shore flies ingested sporangia of Phytophthora capsici, P. nicotianae, and P. ramorum, but they were not viable upon excretion. In contrast, hyphal swellings of Pythium splendens, $P$. sylvaticum, and $P$. ultimum, chlamydospores of Phytophthora ramorum, and oospores of Pythium aphanidermatum, retained their viability after passage through the digestive tract of these larvae. Snails were capable of ingesting and excreting viable sporangia and chlamydospores of P. ramorum, which upon excretion infected detached leaves. Although the impact of larvae and snails in the rapid dissemination of pathogen propagules is unknown, this work does highlight the possibility that some often-ignored animal-fungus interactions should be considered in long-range dispersal of pathogen propagules via food webs.
\end{abstract}

Adult shore flies (Scatella stagnalis (Fallen)) and fungus gnats (Bradysia impatiens (Johannsen)) have been reported to function as aerial vectors of several plant pathogenic fungi, i.e., Fusarium, Verticillium, and Thielaviopsis $(3,5,13,21)$. Although these fungi are soilborne, rootinfecting pathogens, they also sporulate on aboveground portions of their hosts. The aboveground propagules of these fungi (hyphal swellings, microsclerotia, and/or chlamydospores) serve as a source of inoculum for insect acquisition, via internal and external contamination, and subsequent aerial dissemination. Aerial dissemination by insects can provide an additional means of spread for some soilborne pathogens and can greatly impact the management of such diseases under field and greenhouse production systems. However, with the exception of a single report on the aerial transmission of Pythium aphanidermatum by adult shore flies (8), there is no information regarding the role of these insects as vectors of other oomycetes, a major group of extremely destructive rootinfecting pathogens. These pathogens produce diverse reproductive structures (i.e., oospores, hyphal swellings, sporangia, and chlamydospores) ranging in size from 20

Corresponding author: N. Hyder

E-mail: naveen.hyder@ucr.edu

Accepted for publication 20 March 2009.

doi:10.1094/PDIS-93-7-0720

(C) 2009 The American Phytopathological Society to $60 \mu \mathrm{m}$ on colonized roots. Their belowground location, however, could preclude acquisition by adult life stages of both shore flies and fungus gnats, which live strictly aboveground. However, some species of oomycetes also produce aboveground reproductive structures that could be vectored by these insects by ingestion and defecation or casual contact. For example, sporangia and chlamydospores of Phytophthora ramorum are produced on leaves of colonized hosts (2), and sporangia/oospores of $P$. capsici and $P$. nicotianae can be produced on aerial parts of colonized hosts $(1,6,11)$. Additionally, larvae of shore flies and fungus gnats feed belowground and could acquire propagules of Pythium species in infected plant roots.

In addition to insects, snails also have been implicated as vectors of oomycetes $(16,23)$. The role of snails in transmitting Phytophthora citricola among avocado trees has been documented by ElHamalawi and Menge (4). Here, feces of snails collected from avocado groves contained viable oospores and hyphal fragments of $P$. citricola, and in greenhouse experiments, snails exposed to infected avocado plants or infected avocado cuttings were able to transmit the disease to healthy avocado plants via feces or direct contact.

Phytophthora ramorum, the causal agent of Ramorum blight, thrives in moist conditions that also favor high snail populations, making it potentially possible for snails to ingest aboveground propagules of $P$. ramorum and spread the pathogen via infested feces.

The specific objectives of our research were to (i) assess the potential of fungus gnats and shore flies to ingest and excrete propagules of Phytophthora capsici, $P$. nicotianae, $P$. ramorum, Pythium aphanidermatum, $P$. splendens, $P$. sylvaticum, and $P$. ultimum and the ability of these excreted propagules to initiate infection, and (ii) evaluate ingestion, excretion, and transmission of Phytophthora ramorum by brown garden snails (European brown snail), Helix (Cytoomyphalus) aspersa Müller.

\section{MATERIALS AND METHODS}

Oomycete pathogens. Three species of Phytophthora and four species of Pythium were selected for this study (Table 1). These oomycetes were specifically chosen because they are recognized as major pathogens of diverse greenhouse crops. Additionally, the various propagules produced by these oomycetes provided us the opportunity to assess the survivability of these propagules in the digestive tract of the insects investigated. Stock cultures of the oomycetes were maintained on $10 \%$ V8 juice agar unless otherwise specified.

Pathogen cultures. Two methods were employed to produce large quantities of oomycete propagules: cultivation in liquid culture and cultivation in/on infected host tissue. For cultivation of Phytophthora nicotianae, Pythium aphanidermatum, $P$. splendens, $P$. sylvaticum, and P. ultimum,

Table 1. Characteristics of Oomycetes selected for investigation

\begin{tabular}{llcl}
\hline Oomycete & Propagule type & Average size $(\boldsymbol{\mu})$ & Source \\
\hline Phytophthora capsici & Sporangia & $60 \times 36$ & Pepper \\
P. nicotianae & Sporangia & $40 \times 29$ & Citrus \\
P. ramorum & Sporangia & $55 \times 25$ & Recycled water \\
$P$. ramorum & Chlamydospores & $46-60$ & Camellias \\
Pythium aphanidermatum & Oospores & 20 & Cucumbers \\
$P$. splendens & Hyphal swellings & 43 & Easter lily \\
$P$. sylvaticum & Hyphal swellings & 32 & Lettuce \\
$P$. ultimum & Hyphal swellings & 25 & Lettuce \\
\hline
\end{tabular}


7-mm-diameter plugs of 48-h-old V8 agar (10\% V8 juice, $2 \%$ agar, $\left.0.1 \% \mathrm{CaCO}_{3}\right)$ cultures of each pathogen were placed separately in 90 -mm-diameter petri plates containing $15 \mathrm{ml}$ of sterile distilled water (SDW) and two autoclaved rolled oats $(0.7$ $\times 0.4 \mathrm{~cm}$ ) (Quaker Oats Company, Chicago, IL). Cultures were incubated at $25^{\circ} \mathrm{C}$ for 14 days, during which time the various propagules (sporangia, oospores, or hyphal swellings [Table 1]) were produced on the mycelial mats.

For cultivation of Phytophthora ramorum, isolates P10467 (which readily produced chlamydospores in culture) and P10102 (which readily produced sporangia in culture) (The World Phytophthora Genetic Resource Collection [WPC]), 7-mmdiameter plugs of 7-day-old cultures maintained on PARPH selective media (cornmeal agar amended with pimaricin, ampicillin, rifampicin, $\mathrm{PCNB}$, and hymexazol [14]) were transferred to $15 \mathrm{ml}$ of $5 \% \mathrm{~V} 8$ broth in petri plates and incubated at $25^{\circ} \mathrm{C}$ for 30 days, during which time abundant chlamydospores and/or sporangia were produced on the mycelial mats.

For cultivation of $P$. capsici, eggplant fruits (Solanum melongena $\mathrm{L}$.) were inoculated with 8-mm-diameter plugs of 48-hold V8 agar cultures and placed in a moist chamber. After 8 days at $25^{\circ} \mathrm{C}$, numerous sporangia were produced on the surface of infected fruit.

Maintenance and collection of insects. A colony of shore flies (S. stagnalis) naturally occurring in the greenhouse was maintained on algal-infested rockwool blocks $(7 \times 14 \times 90 \mathrm{~mm})$ in a greenhouse at 25 to $30^{\circ} \mathrm{C}$ with a 12 -h photoperiod at $100 \%$ relative humidity. Algae originating from adult shore flies were used to establish the colony. The rockwool blocks were fertilized weekly with Miracle-Gro (3 g product per liter of water, Scotts MiracleGro Products, Inc., Marysville, $\mathrm{OH})$. Adult shore flies were collected by aspiration, and larvae and pupae were picked up with a dissecting needle under a dissecting microscope, both from insect-infested rockwool blocks.

Fungus gnats (B. impatiens) naturally occurring in the greenhouse were maintained on disease-free pepper plants (Capsicum annuum L. cv. Joe E. Parker) growing in UC mix (a 1:1 mixture of \#30 silica sand and peat moss) in $11 \times 11 \mathrm{~cm}$ plastic pots, at 25 to $30^{\circ} \mathrm{C}$ with a 12 -h photoperiod at $100 \%$ relative humidity. Larvae were periodically examined microscopically to ensure that they were free of external and internal contamination (examination of frass deposits) by fungal pathogens. Larvae and pupae were collected from the top $2 \mathrm{~cm}$ of the potting mix around the base of plants by rinsing the mix through a 32-mesh sieve. The larvae and pupae retained on the sieve were backwashed into petri plates with $15 \mathrm{ml}$ of water and collected with a dissecting nee- dle under a dissecting microscope. Adult fungus gnats do not feed on fungi (9) and thus were not evaluated for ingestion and egestion of pathogen propagules.

In all experiments, insects fed on rolled oats were included as controls. These insects excreted frass but were found not to be internally infested by the pathogens. The numbers of fungus gnat and shore fly larvae and shore fly adults varied among experiments due to their availability and/or mortality at and during the time the experiment was performed. Additionally, for the same reasons mentioned above, not all life stages of both insects were used for all the studies.

Pathogen ingestion and excretion by adult shore flies. All test species except $P$. ramorum were evaluated for their ability to survive ingestion and egestion by adult shore flies. Currently, $P$. ramorum is a quarantined pest (24), and therefore to avoid the risk of contaminated shore flies escaping and spreading the pathogen outside of the containment area, $P$. ramorum was not included in this set of studies. Mycelial mats of Phytophthora nicotianae, Pythium aphanidermatum, $P$. splendens, $P$. sylvaticum, and P. ultimum bearing numerous propagules (Table 1), produced as described above, were removed from petri dishes, rinsed in SDW, placed on a paper towel to remove excess moisture, and then placed in separate petri plates $(90 \mathrm{~mm}$ diameter). Additionally, four pieces of the colonized eggplant fruit $(2 \times 2 \mathrm{~cm})$ bearing sporulating colonies of $P$. capsici were also placed in a separate petri plate $(90 \mathrm{~mm}$ diameter). Fifteen to 132 adult shore flies from colonies maintained in the greenhouse were temporarily incapacitated by exposing them to $0^{\circ} \mathrm{C}$ for $5 \mathrm{~min}$ and then transferred to each petri plate to feed on the above cultures. The petri plates were incubated at room temperature $\left(25^{\circ} \mathrm{C}\right)$ for $24 \mathrm{~h}$, during which time hundreds of frass deposits were observed on the undersides of the lids of the petri plates. Approximately 10 to 33 frass deposits from each lid were randomly examined microscopically $(\times 200)$ for the presence of propagules. Then, sections of solidified $1 / 2$-strength PDA, measuring $3 \times 3 \times 0.2 \mathrm{~cm}$, were overlaid on the frass deposits to facilitate transfer of the deposits to the agar. After $24 \mathrm{~h}$, the agar sections were removed and placed in separate petri plates and incubated at $25^{\circ} \mathrm{C}$. Propagule germination was recorded after $48 \mathrm{~h}$. These experiments were conducted three times for each pathogen.

Pathogen ingestion and excretion by larvae of fungus gnats and shore flies. Mycelial mats bearing propagules of Phytophthora capsici, $P$. nicotianae, $P$. ramorum [isolates $\mathrm{P} 10102$ and P10467], Pythium aphanidermatum, $P$. splendens, $P$. sylvaticum, and $P$. ultimum were obtained by the procedures described above (Table 1). Fungus gnat and shore fly larvae were allowed to feed on these propagules for 24 h. The larvae were collected, rinsed twice in SDW, and examined microscopically $(\times 200)$ for the presence of propagules in their intestinal tracts. Larvae which were internally infested with propagules were placed individually on petri plates containing water agar and incubated at $25^{\circ} \mathrm{C}$. Within $2 \mathrm{~h}$, one to 13 discrete frass deposits were observed on the surface of the agar in each petri plate. Frass deposits were examined microscopically $(\times 200)$ to confirm the presence, condition, and number of propagules in each deposit; each frass speck was then incubated at $25^{\circ} \mathrm{C}$ for $24 \mathrm{~h}$ to assess propagule viability, i.e., germination. Frass deposits containing propagules of $P$. ramorum were overlaid with PARPH medium and incubated at $25^{\circ} \mathrm{C}$ for 24 to $72 \mathrm{~h}$ to assess propagule viability. The experiment with $P$. aphanidermatum was conducted twice, and all the other experiments were conducted 3 times per pathogen, and 10 to 20 insects were assayed per experiment.

Pathogen acquisition and excretion by garden snails. Brown garden snails were collected from a natural population at a residential landscape location in southern California and fed on moistened rolled oats for $18 \mathrm{~h}$ to clean out their digestive tracts. Six snails were then rinsed in SDW and placed individually in 90-mm-diameter petri plates containing mycelial mats of $P$. ramorum (isolate P10467) bearing abundant sporangia and chlamydospores for 24 h. Frass ribbons excreted by these snails were collected, gently rinsed with SDW, and microscopically examined $(\times 40)$ for the presence and condition of excreted propagules of $P$. ramorum. Frass ribbons containing propagules were added to a 2$\mathrm{ml}$ microcentrifuge tube containing $1 \mathrm{ml}$ of SDW and vortexed for $60 \mathrm{~s}$ to dislodge the propagules from the ribbon. Three 0.1-ml aliquots of the suspension were then dispensed on the surface of a 90-mmdiameter petri plate containing $\mathrm{PARPH}$ medium and incubated at $25^{\circ} \mathrm{C}$ to observe germination of excreted propagules. Controls consisted of six snails whose frass was harvested after they were fed on rolled oats. The experiment was conducted three times.

Transmission studies. Transmission of Pythium by larvae of fungus gnats. All transmission studies were conducted using a modified method developed by Misaghi (20). Approximately one-fourth of a 4mm-thick water agar slab was removed from one side of a 90-mm-diameter petri plate and discarded. Five surface-sterilized pepper seeds (Capsicum annuum L. cv. Joe E. Parker), susceptible to all species of Pythium used in this study, were inserted equidistantly into the cut edge of the agar retained in the petri plate. The petri plates were stacked on edge in a plastic crisper $(29.8 \times 12.4 \times 6.2 \mathrm{~cm})($ Tri-State Plastics, Inc., Latonia, KY) with the seeds facing up and incubated at $28^{\circ} \mathrm{C}$ in the dark until 
germination occurred. Fungus gnat larvae were allowed to feed on sporulating cultures of $P$. splendens, $P$. sylvaticum, and $P$. ultimum, produced as described above, for $24 \mathrm{~h}$. The larvae were then rinsed with SDW and microscopically examined for the presence of hyphal swellings in their digestive tracts. Two internally infested larvae were then placed in each petri plate containing 9-day-old pepper seedlings. Petri plates with pepper seedlings without fungus gnat larvae and petri plates with pepper seedlings with fungus gnat larvae not fed with Pythium spp. served as negative controls. Pepper seedlings inoculated by placing 7-mm-diameter plugs from the edge of actively growing cultures of each Pythium species on the agar substrate in which the seedlings were growing served as positive controls. All plates were incubated at $28^{\circ} \mathrm{C}$ in a growth chamber $(12 \mathrm{~h}$ photoperiod), and seedling mortality data were collected over the next 2 weeks. Experiments with each pathogen were conducted twice, and three petri plates (5 seedlings/petri plate) were used in each experiment.

Transmission of Phytophthora ramorum by larvae of fungus gnats. Detached rhododendron leaves (Rhododendron spp. L. cv. Cunningham's Blush) were surfacesterilized $(0.5 \% \mathrm{NaOCl}$ for $2 \mathrm{~min}$ and rinsed with SDW) and wounded by cutting

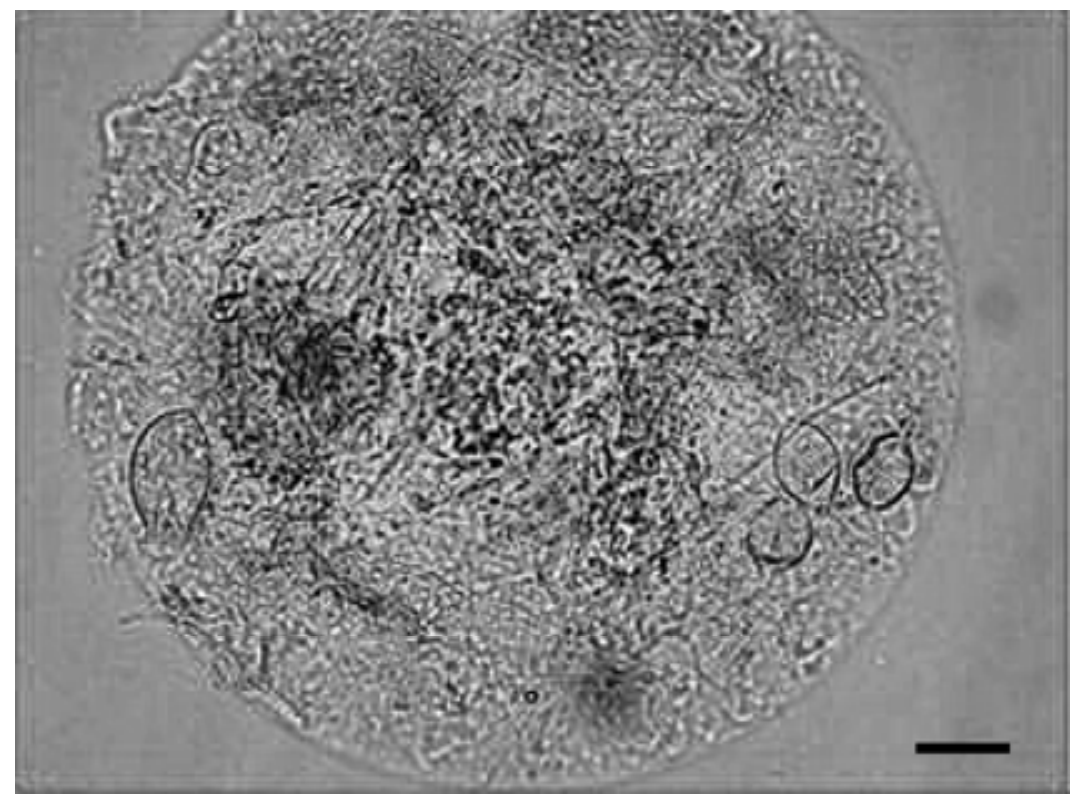

Fig. 1. Plasmolyzed/empty sporangia of Phytophthora capsici in the frass deposit of an adult shore fly. $\mathrm{Bar}=60 \mu \mathrm{m}$.

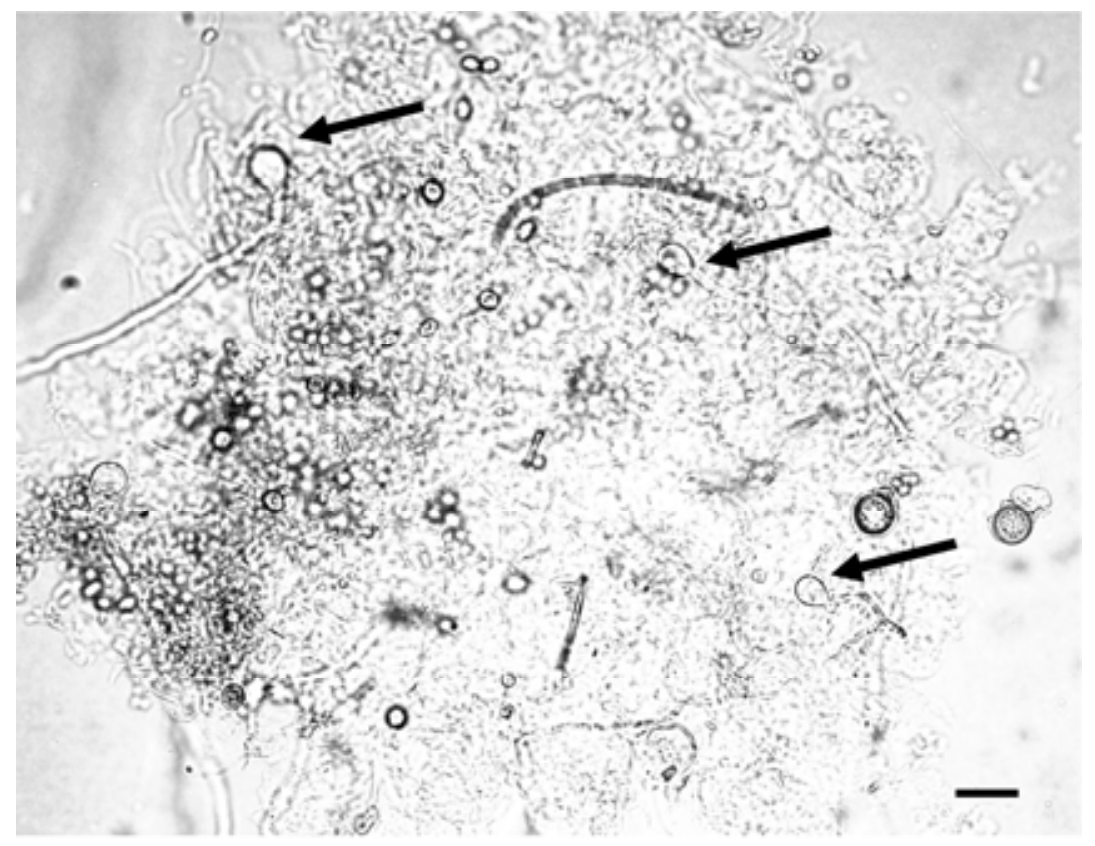

Fig. 2. Frass excreted by adult shore fly showing germinated oospores (arrows) of Pythium aphanidermatum. $\mathrm{Bar}=25 \mu \mathrm{m}$

off the margins at the apical and the basal ends. Each leaf was placed in a $90-\mathrm{mm}$ diameter petri plate containing $10 \mathrm{ml}$ of SDW. One moist sterile rolled oat seed was placed on the leaf as a food source for the fungus gnat larvae. Two fungus gnat larvae, internally infested with chlamydospores of $P$. ramorum (isolate P10467) (fed on $P$. ramorum for $24 \mathrm{~h}$ ), were placed on each leaf. The petri plates were incubated at $25^{\circ} \mathrm{C}$ for 10 days, after which time the leaves were examined microscopically $(\times 100$ and $\times 200)$ for necrosis of tissue and colonization (presence of hyphae and chlamydospores either on leaf margins or embedded in cleared leaf tissue). In order to observe the mycelium, chlamydospores, and sporangia of $P$. ramorum inside the leaf tissue, the leaves were cleared in $1: 1$ acetic acid and ethanol and stained with lactic acid and aniline blue using a modified technique developed by McLean and Byth (19). Rhododendron leaves placed in SDW without fungus gnat larvae and leaves in SDW with non- $P$. ramoruminfested fungus gnat larvae served as controls. The experiment was conducted three times with 12 replicates (2 fungus gnat larvae/rhododendron leaf/petri plate) each.

Transmission of $\mathrm{P}$. ramorum by garden snails. Snails, collected as previously described, were fed overnight on moistened rolled oats to clean out their digestive tracts, rinsed in SDW, and then allowed to feed on mycelial mats bearing sporangia and chlamydospores of either $P$. ramorum isolate P10467 or P10102. After a 24-h acquisition period, snails were rinsed with SDW and placed individually in a petri plate containing one surface-sterilized wounded rhododendron leaf and $10 \mathrm{ml}$ of SDW. Additionally, one frass ribbon excreted by each snail was collected, rinsed in SDW, and microscopically examined $(\times 200)$ for the presence of $P$. ramorum propagules. Frass ribbons containing propagules of $P$. ramorum were transferred to a petri plate containing a surface-sterilized rhododendron leaf and $10 \mathrm{ml}$ of SDW. Plates were incubated at $25^{\circ} \mathrm{C}$ for 7 to 10 days, and the leaves were periodically examined for necrosis of tissue and colonization (presence of hyphae and chlamydospores either on leaf margins or embedded in leaf tissue). Experiments with isolate P10467 were conducted 5 times with 8 replicates (1 snail/ rhododendron leaf/petri plate) each, and experiments with isolate P10102 was conducted twice with 7 replicates $(1$ snail/rhododendron leaf/petri plate) each. Snails not fed on $P$. ramorum and snail frass from noninfested snails placed on rhododendrons leaves served as controls.

\section{RESULTS}

Pathogen ingestion and excretion by shore fly adults. Sporangia and/or hyphal swellings of Phytophthora capsici, P. nicotianae, Pythium splendens, $P$. sylvaticum, and $P$. ultimum were ingested by adult 
shore flies, but none of those propagules retained their viability after passage through the digestive tract. All frass deposits excreted by these adults (approximately 9 frass deposits/adult/24-h period) were microscopically examined, and no viablelooking propagules were detected nor did any propagules germinate. Excreted propagules were observed in various stages of lysis/plasmolysis (dissolved papillae, disrupted plasma membrane, digested cytoplasm) in frass deposits (Fig. 1).

In contrast, oospores of $P$. aphanidermatum ingested by adult shore flies were viable upon excretion (Fig. 2). In three experiments, an average of 65 to $78 \%$ (mean 73) of the frass deposits examined contained viable oospores. The number of oospores in each infested deposit ranged from 10 to 70 (mean 32). Thirty-six percent of the excreted frass deposits germinated upon incubation at $35^{\circ} \mathrm{C}$. Morphological and physiological characteristics were used to identify and confirm the identity of the fungus emerging from the frass deposits as $P$. aphanidermatum $(6,25)$.

In all assays, no test pathogens were ever detected on or in insects that were not allowed to feed on the pathogens.

Pathogen ingestion and excretion by larvae of fungus gnats and shore flies. Fungus gnat and shore fly larvae were capable of ingesting sporangia of Phytophthora capsici, $P$. nicotianae, and $P$. ramorum (isolates P10467 and P10102), but excreted sporangia were either empty or in various stages of plasmolysis (Fig. 3A to C). In contrast, chlamydospores, hyphal swellings, and oospores of these oomycetes retained their viability after passing through the digestive tract of both fungus gnat and shore fly larvae and were able to germinate upon incubation (Fig. 4A to E, Table 2).

Sixty-two to $71 \%$ (mean $=67$ ) of the shore fly larvae assayed (45 in three experiments per pathogen) for each of the three pathogens, $P$. splendens, $P$. sylvaticum, and $P$. ultimum, excreted at least one frass deposit that contained viable hyphal swellings. The number of hyphal swellings per frass deposit ( 1 to 5 frass deposits/insect) ranged from 6 to 60 (Table 2). Developing colonies were traced back to hyphal swellings in each frass deposit. Between 51 and $89 \%$ (mean $=74$ ) of the fungus gnat larvae tested (45 in three experiments per pathogen) excreted at least one frass deposit containing viable hyphal swellings of each of the three Pythium species.

A mean of $6 \%$ of the shore fly larvae that fed on P. ramorum (isolate P10102) (34 in three experiments) excreted viable chlamydospores, and the number of chlamydospores per frass deposit ( 1 to 3 deposits/ larvae) ranged from 2 to 5 chlamydospores. Developing colonies were traced back to chlamydospores in each frass deposit.

A mean of $40 \%$ of the fungus gnat larvae (60 in 3 experiments) that fed on $P$. ramorum (isolate P10467) excreted viable chlamydospores, and the number of chlamydospores per frass deposit ( 2 to $13 \mathrm{de}$ posits/larvae) ranged from 1 to 25 . Developing colonies were traced back to chlamydospores in the frass deposits. No attempt was made to estimate the percent germination of the excreted propagules.
Additionally, a mean of $77 \%$ of the fungus gnat larvae (30 in three experiments) that fed on Pythium aphanidermatum excreted at least one frass deposit containing viable oospores. The number of oospores per frass deposit (2 to 8) ranged from 10 to 55 . Developing colo-

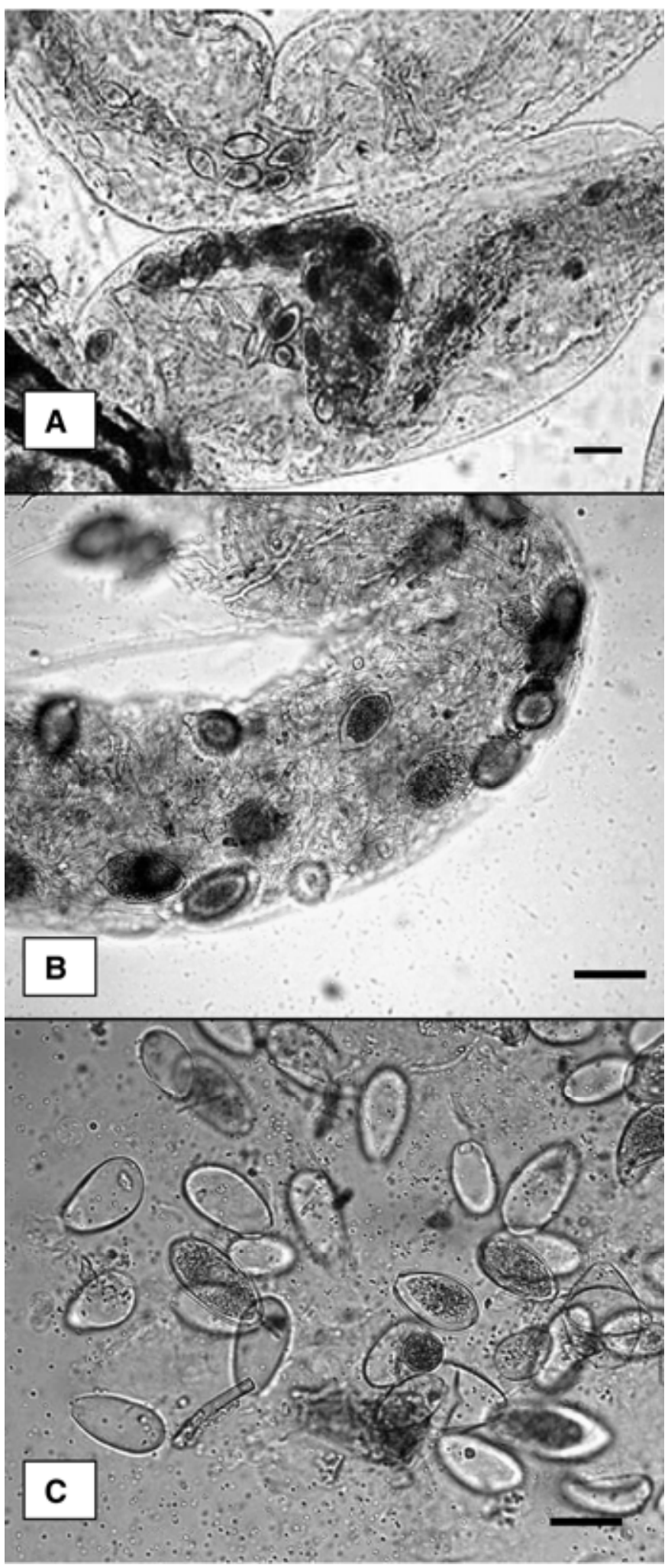

Fig. 3. A and B, Plasmolyzed/empty sporangia of Phytophthora capsici in the digestive tracts of shore fly larvae. Bar $=60 \mu \mathrm{m}$. C, Plasmolyzed/empty sporangia of Phytophthora ramorum in the frass deposit of a fungus gnat larvae. $\mathrm{Bar}=55 \mu \mathrm{m}$. 
nies were traced back to hyphal swellings in each frass deposit.

Pathogen acquisition and excretion by garden snails. Garden snails ingested and excreted chlamydospores as well as sporangia of $P$. ramorum. In three experiments (6 snails/experiment), a mean of $67 \%$ of the snails ingested and excreted viable sporan- gia and chlamydospores of $P$. ramorum (isolate P10467). An average of 200 chlamydospores obtained from each frass sample germinated with multiple germ tubes $(2$ to 7 per propagule within $24 \mathrm{~h}$ of excretion). An average of 200 sporangia from each frass sample germinated directly with a single germ tube (Fig. 5). Frass excreted by snails not fed on $P$. ramorum was devoid of propagules of $P$. ramorum.

Transmission studies. Transmission of Pythium by larvae of fungus gnats. Fungus gnat larvae fed on either $P$. splendens, $P$. sylvaticum, or $P$. ultimum were able to transmit the pathogens to healthy pepper seedlings grown in petri plates (Fig. 6).
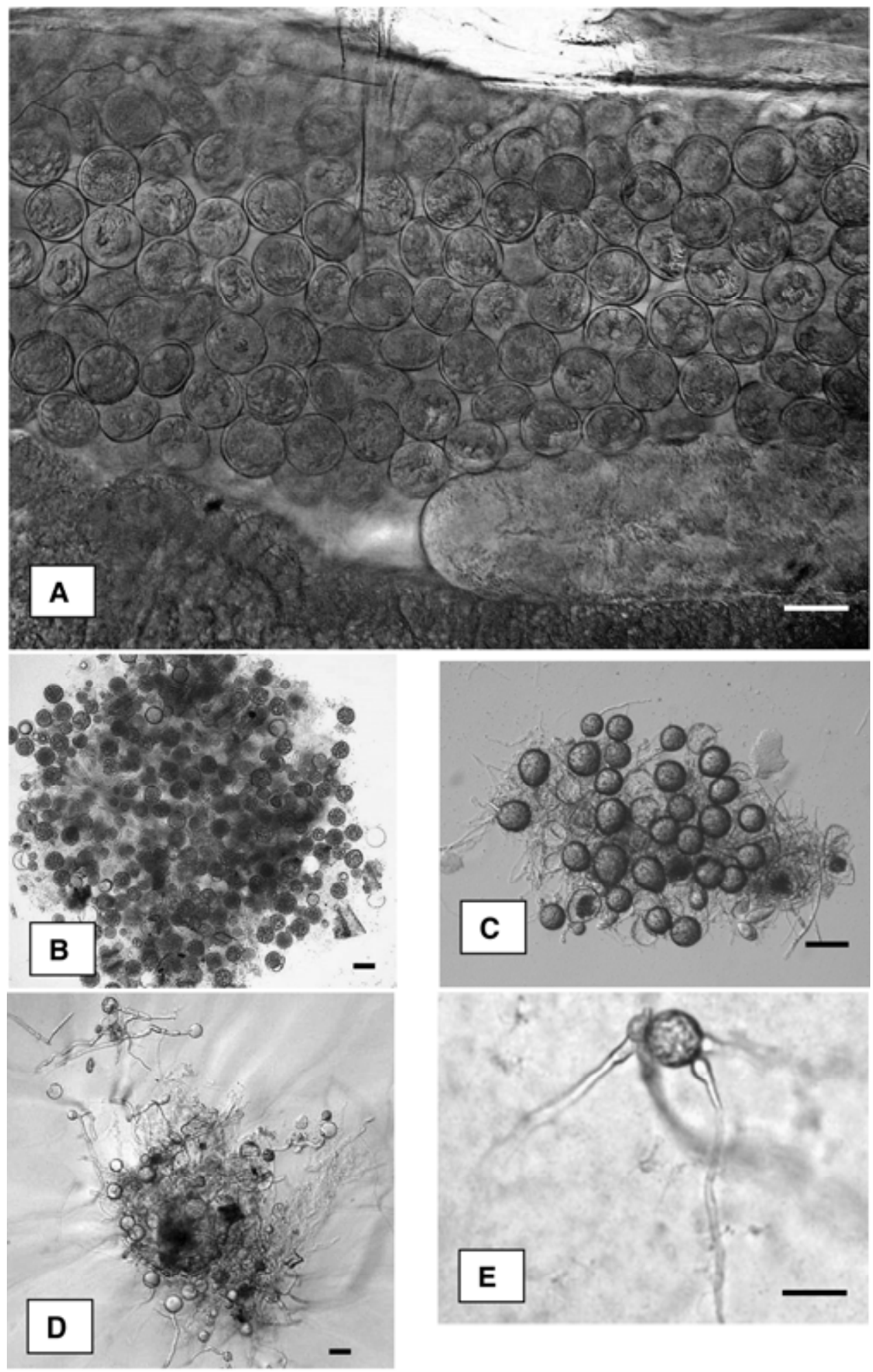

Fig. 4. A, Hyphal swellings of Pythium splendens in the digestive tract of a fungus gnat larva. B, Hyphal swellings of $P$. splendens in the frass deposit of a fungus gnat larva. C, Chlamydospores of Phytophthora ramorum in the frass deposit of a fungus gnat larva. D, Frass excreted by a fungus gnat larva showing germinated hyphal swellings of $P$. splendens. E, Germinated chlamydospores of $P$. ramorum in frass of a fungus gnat larva. Bars in A, B, and D $=43 \mu \mathrm{m}$. Bars in $\mathrm{C}$ and $\mathrm{E}=55 \mu \mathrm{m}$. 
The mean percentages of seedlings killed by $P$. splendens, $P$. sylvaticum, and $P$. ultimum (in both experiments per pathogen) within 2 weeks of introduction of pathogen-infested larvae to the seedlings were $28.6,35.7$, and $66.7 \%$, respectively. Symptoms included necrosis of stem tissue and root rot. The respective pathogens were reisolated from diseased seedlings. All control plants remained healthy.

Transmission of Phytophthora ramorum by larvae of fungus gnats. Chlamydospores of $P$. ramorum (isolate P10467) excreted by fungus gnat larvae were able to infect and colonize detached wounded rhododendron leaves. Abundant chlamydospores, as well as a few sporangia, were observed along the wounded leaf margins and/or within cleared leaf tissue. In three experiments (12 fungus gnat larvae/experiment), a mean of $44 \%$ of the rhododendron leaves were symptomatically infected with $P$. ramorum within 10 days after the introduction of the pathogen-infested larvae.

Transmission of $\mathrm{P}$. ramorum by garden snails. A mean of $23 \%$ of snails (40 in five experiments) internally infested with sporangia and chlamydospores of $P$. ramorum (isolate P10467) infected healthy rhododendron leaves. A mean of $31 \%$ of frass samples (one from each of 36 snails in five experiments) collected from these snails contained viable propagules that infected healthy rhododendron leaves. Additionally, a mean of $14 \%$ of snails (14 in two experiments) internally infested with $P$. ramorum (isolate $\mathrm{P} 10102)$ and a mean of $43 \%$ frass samples (one from each of 14 snails in two experiments) collected from these snails contained viable sporangia which infected healthy rhododendron leaves. Snails not fed on P. ramorum and frass excreted by these snails did not contain propagules of $P$. ramorum and therefore were not able to initiate infections in rhododendron leaves.

\section{DISCUSSION}

Exclusion of plant pathogens from greenhouse production systems is dependent upon understanding all avenues of pathogen introduction and spread. Once mechanisms of introduction and dispersal are identified, specific management strategies can be developed to exclude pathogens from production areas. We demonstrated that common greenhouse pests and snails are capable of vectoring several oomycetes. Our findings complement and extend earlier work that implicates common greenhouse insects as vectors of several plant pathogenic fungi $(3,5,13,21)$. With the exception of oospores of P. aphanidermatum, adult shore flies are not capable of ingesting and excreting viable hyphal swellings, chlamydospores, or sporangia of three species of Pythium and two species of Phytophthora (Table 3). Thus, they are unlikely to function as aerial vectors of the oomycetes we investigated. However, larval stages of both fungus gnats and shore flies ingested and excreted viable hyphal swellings of $P$. splendens, . sylvaticum, and P. ultimum as well as chlamydospores of $P$. ramorum, implicating them as potential vectors of these oomycetes (Table 3). Sporangia of $P$. aphanidermatum, $P$. ramorum, $P$. capsici, and $P$. nicotianae, although ingested by larvae, were not viable upon excretion. The papillae of all three species of Phytophthora, as well as the sporangial cytoplasm, were digested during passage through the intestinal tract of the insect. The papillae of sporangia are composed of a gel-like substance (18) that appeared to have been dissolved upon passing through the intestinal tract of the larvae.

Although larvae of these greenhouse insect pests may not contribute to the rapid transmission of these oomycetes, they may play a role in the introduction of the pathogen into a production facility via larvalinfested cuttings and horticultural substrates. Once introduced, these oomycetes could be dispersed by the recirculating irrigation water or through high-density "community flats" via root-to-root contact and infect the entire crop within the system. In a commercial nursery where $P$. ramorum was found in 2003, most infections originated in community flats where nursery seedlings were raised (B. Reddy, Monrovia Growers, personal communication).
Our studies indicate that land snails, which are common nursery, greenhouse, and garden pests, are capable of ingesting and excreting viable propagules of Phytophthora ramorum. $P$. ramorum is pathogenic to numerous ornamental plants, and environmental conditions favorable to this pathogen, i.e., cool, moist, and shady conditions, are also conducive to snails. Thus, snails have the opportunity to acquire and the ability to disperse the pathogen, albeit slowly, within a facility and serve as transient vectors for long-distance movement during the marketing of plants.

The ability of vertebrates and invertebrates to disperse ectomycorrhizal fungi has been documented (17). Fungivores such as mites, springtails, millipedes, beetles, and fly larvae were found to acquire spores of Tomentella sublilacina as a result of feeding on mature sporocarps of this mycorrhizal fungus. Vertebrate and invertebrate predators of these fungivores can indirectly acquire these pathogen propagules. Several fungivores and their predators contain fungal spores in their intestinal tracts and/or their excreta (17). For example, viable spores of aquatic phycomycetes were found in the excreta of birds that had fed on worms that in turn had ingested various soil fungi (22). Birds have also

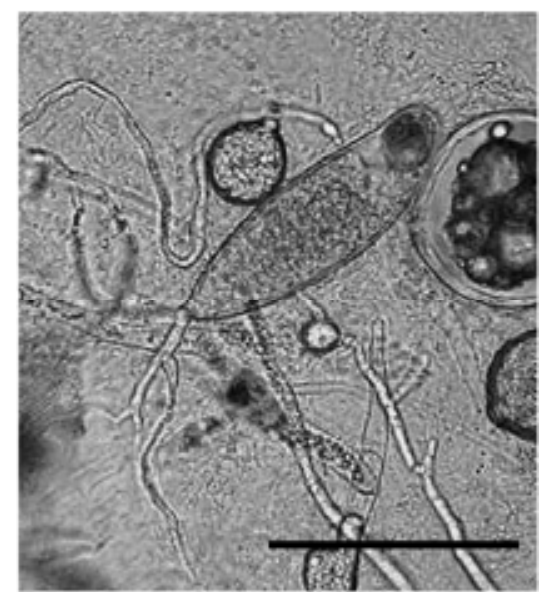

Fig. 5. Germinated sporangia of Phytophthora ramorum in snail frass. Bar $=55 \mu \mathrm{m}$.

Table 2. Propagules of Phytophthora and Pythium species and their survival through the intestinal tract of larvae of fungus gnats and shore flies ${ }^{\mathrm{a}}$

\begin{tabular}{|c|c|c|c|c|c|}
\hline \multirow[b]{2}{*}{ Oomycete } & \multirow[b]{2}{*}{ Propagule type } & \multicolumn{2}{|c|}{ Fungus gnat larvae } & \multicolumn{2}{|c|}{ Shore fly larvae } \\
\hline & & $\begin{array}{c}\% \text { that excreted } \\
\text { propagules }\end{array}$ & $\begin{array}{c}\% \text { that excreted } \\
\text { viable propagules }\end{array}$ & $\begin{array}{l}\% \text { that excreted } \\
\text { propagules }\end{array}$ & $\begin{array}{c}\% \text { that excreted } \\
\text { viable propagules }\end{array}$ \\
\hline Phytophthora capsici & Sporangia & 100 & 0 & 100 & 0 \\
\hline P. nicotianae & Sporangia & 100 & 0 & 100 & 0 \\
\hline \multirow[t]{2}{*}{ P. ramorum (10467) } & Sporangia & - & - & $\mathrm{nt}^{\mathrm{b}}$ & nt \\
\hline & Chlamydospores & $48 \pm 5.8$ & $40 \pm 5.8$ & nt & $\mathrm{nt}$ \\
\hline \multirow[t]{2}{*}{ P. ramorum (10102) } & Sporangia & $73 \pm 5.8$ & 0 & $44 \pm 5.4$ & 0 \\
\hline & Chlamydospores & - & - & $21 \pm 7.7$ & $6 \pm 5.4$ \\
\hline Pythium aphanidermatum & Oospores & $83 \pm 5.8$ & $77 \pm 5.8$ & nt & nt \\
\hline P. splendens & Hyphal swellings & $89 \pm 10.2$ & $89 \pm 10.2$ & $78 \pm 3.9$ & $71 \pm 10.2$ \\
\hline P. sylvaticum & Hyphal swellings & $82 \pm 7.7$ & $82 \pm 7.7$ & $71 \pm 13.9$ & $62 \pm 10.2$ \\
\hline P. ultimum & Hyphal swellings & $69 \pm 7.7$ & $51 \pm 10.2$ & $71 \pm 20.4$ & $67 \pm 17.7$ \\
\hline
\end{tabular}

\footnotetext{
${ }^{a}$ Each value is a mean of three experiments, each with 10 to 20 replications \pm SD.
}

${ }^{\mathrm{b}} \mathrm{nt}=$ Not tested. 


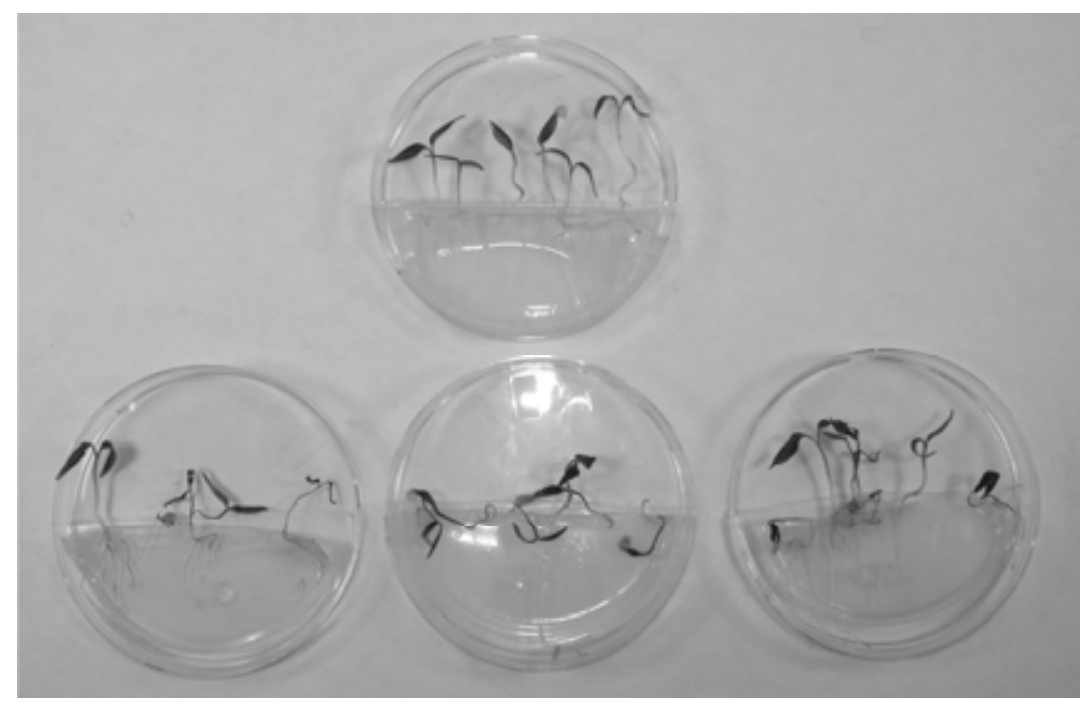

Fig. 6. Growth chamber transmission studies demonstrating that hyphal swellings of Pythium splendens, $P$. sylvaticum, and $P$. ultimum excreted by fungus gnat larvae were able to infect pepper seedlings and cause disease. Controls show healthy seedlings.

Table 3. Summary of ingestion and excretion of viable pathogen propagules by various life stages of shore flies and fungus gnats

\begin{tabular}{|c|c|c|c|c|}
\hline \multirow[b]{2}{*}{ Pathogen (propagule) } & \multicolumn{2}{|c|}{ Fungus gnats ${ }^{a}$} & \multicolumn{2}{|c|}{ Shore flies ${ }^{\mathbf{a}}$} \\
\hline & Adult & Larvae & Adult & Larvae \\
\hline Phytophthora capsici (sporangia) & nt & No & No & No \\
\hline Phytophthora nicotianae (sporangia) & $\mathrm{nt}$ & No & No & No \\
\hline Phytophthora ramorum (sporangia) & nt & No & nt & No \\
\hline Phytophthora ramorum (chlamydospores) & nt & Yes & $\mathrm{nt}$ & Yes \\
\hline Pythium aphanidermatum (oospores) & $\mathrm{nt}$ & Yes & Yes & nt \\
\hline Pythium splendens (hyphal swellings) & $\mathrm{nt}$ & Yes & No & Yes \\
\hline Pythium sylvaticum (hyphal swellings) & nt & Yes & No & Yes \\
\hline Pythium ultimum (hyphal swellings) & nt & Yes & No & Yes \\
\hline
\end{tabular}

${ }^{\mathrm{a}} \mathrm{No}=$ propagules not ingested or excreted by the insect. Yes = propagules ingested and excreted by the insect in a viable form. $\mathrm{nt}=$ not tested.

been implicated in disseminating Cylindrocladium parasiticum by ingesting infected peanuts and depositing its microsclerotia in droppings (12). Ants have been shown to move Phytophthora palmivora vertically through infected cocoa trees (7), and chlamydospores of $P$. cinnamomi have been shown to be vectored by birds and termites (15). Colletotrichum lagenarium has also been shown to survive the gut of white garden snails (10). Thus, pathogen infested insects and snails could potentially facilitate dispersal of propagules in food webs. If birds were to prey on snails and/or larvae that are internally infested with sporangia or chlamydospores of $P$. ramorum, they can potentially disperse the propagules over longer distances during flight albeit at a very low probability. Birds have been suspected of vectoring P. ramorum (2).

Control of fungus gnats, shore flies, and snails is an ongoing problem in greenhouse systems. Historically, fungus gnats and shore flies have been considered a nuisance, i.e., deposition of their feces on aerial parts of plants may subsequently diminish the aesthetic and/or market value of the crop. The possibility that they may also serve as vectors of some major patho-
5. El-Hamalawi, Z. A., and Stanghellini, M. E. 2004. Acquisition and aerial dissemination of Fusarium and Verticillium by adult shore flies. (Abstr.) Phytopathology 94:S151.

6. Erwin, D. C., and Ribeiro, O. K. 1996. Phytophthora Diseases Worldwide. American Phytopathological Society, St. Paul, MN.

7. Evans, H. C. 1973. Invertebrate vectors of $P$. palmivora causing black pod disease of cocoa in Ghana. Ann. Appl. Biol. 75:331-345.

8. Goldberg, N. P., and Stanghellini, M. E. 1990. Ingestion-egestion and aerial transmission of Pythium aphanidermatum by shore flies (Ephydrinae: Scatella stagnalis). Phytopathology 80:1244-1246.

9. Harris, M. A., Gardner, W. A., and Oetting, R. D. 1996. A review of the scientific literature on fungus gnats (Diptera: Sciaridae) in the genus Bradysia. J. Entomol. Sci. 31:252-276.

10. Hasan, S. 1976. Study of the passage of a plant pathogenic fungus Collectotrichum lagenarium through the gut of Euparypha pisana. Ann. Zool. Ecol. Anim. 8:221-230.

11. Hausbeck, M. K., and Lamour, K. H. 2004 Phytophthora capsici on vegetable crops: Research progress and management challenges. Plant Dis. 88:1292-1303.

12. Hiller, R. B. 1975. The role of birds in spreading the Cylindrocladium black rot of peanuts. M.S. thesis. Virginia Polytechnic Institute and University, Blacksburg.

13. Kalb, D. W., and Millar, R. L. 1986. Dispersal of Verticillium albo-atrum by the fungus gnat (Bradysia impatiens). Plant Dis. 70:752-753.

14. Kannwisher, M. E., and Mitchell, D. J. 1978 The influence of a fungicide on the epidemiology of black shank of tobacco. Phytopathology 68:1760-1765.

15. Keast, D., and Walsh, L. G. 1979. Passage and survival of chlamydospores of Phytophthora cinnamomi Rands, the causal agent of Forest Dieback Disease, through the gastrointestinal tracts of termites and wild birds. Appl. Environ. Microbiol. 37:661-664.

16. Kueh, T. K., and Khew, K. L. 1982. Survival of Phytophthora palmivora in soil and after passing through alimentary canals of snails. Plant Dis. 66:897-899.

17. Lilleskov, E. A., and Bruns, T. D. 2005. Spore dispersal of a resupinate ectomycorrhizal fungus, Tomentella sublilacina, via food webs. Mycologia 97:762-769.

18. MacDonald, J. D., and Duniway, J. M. 1978 Influence of the matric and osmotic components of water potential on zoospore discharge in Phytophthora. Phytopathology 68:751-757.

19. McLean, R. J., and Byth, D. E. 1981. Histological studies of the pre-penetration development and penetration of soybeans by rust, Phakopsora pachyrhizi. Syd. Aust. J. Agric. Res. 32:435-443.

20. Misaghi, I. J. 1990. Screening bacteria for root colonization ability by a rapid method. Soil Biol. Biochem. 22:1085-1088.

21. Stanghellini, M. E., Rasmussen, S. L., and Kim, D. H. 1999. Aerial transmission of Thielaviopsis basicola, a pathogen of corn-salad, by adult shore flies. Phytopathology 89:476-479.

22. Thornton, M. L. 1970. Transport of soildwelling aquatic phycomycetes by earthworms. Br. Mycol. Soc. Trans. 55:391-397.

23. Turner, G. J. 1964. Transmission of snails of the species of Phytophthora which causes Foot Rot of Piper nigrum L in Sarawak. Nature 202:1133.

24. U.S. Dep. Agric. Animal Plant and Health Inspection Service: Code of Federal Regulations, Title 7, subpart 301.92 (Phytophthora ramorum), sections 301.92-1 through 301.9211. USDA APHIS website: http://www.aphis. usda.gov/ppq/ispm/sod

25. Van Der Plaats-Niterink, A. J. 1981. Monograph of the Genus Pythium. Centraalbureau voor Schimmelcultures, Baarn, Netherlands. 